\title{
Model Development of Basic Handball Techniques Test Instruments
}

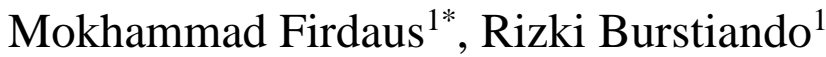 \\ ${ }^{1}$ Universitas Nusantara PGRI Kediri, Indonesia \\ *Corresponding author. Email: m.firdaus@unpkediri.ac.id
}

\begin{abstract}
This study aims to develop an instrument model for basic handball technical skills test. The developed model of the test instrument can be used to support lectures on T / P Handball. This study was conducted by using Borg and Gall's 8 steps research model, consists of (1) field information collection, (2) analysis of collected information, (3) development of early product, (4) expert validation and revision, (5) small scale field trial and revision, (6) big scale field trial and revision, (7) final product making, (8) product effectivity test. A small-scale trial was conducted on 22 Demak Regency handball athletes. Large scale trials were conducted on 30 handball athletes in the city of Surakarta. The instrument used for collecting data are observation, interview, field notes, score scale, effectivity test scoring form, and learn scoring result. The results of this study are a model of the instrument test the basic techniques of handball in the form of procedures, to assess basic handball technical skills which will later be developed to a better stage. From the results of the assessment of experts and practitioners, it can be concluded that the instrument design model of the basic handball technique designed can be categorized as good and effective, so that this test instrument can be suitable for use.
\end{abstract}

Keywords: handball, techniques, test instruments

\section{INTRODUCTION}

Handball is a modification between the game of basketball and football, relying on the finesse of the hand to enter the opponent's goal ball. Handball game is a game like football, but this game uses hands to pass the ball from player to player in their book said that the ball field has a size of $40 \mathrm{~m}$ $\mathrm{x} 20 \mathrm{~m}$ with a dividing line in the middle and a goal in the middle of both short sides [1]. Around the goal line is made to mark the area that only the goalkeeper can enter. The ball used is smaller than the ball. Handball is played for $2 \times 30$ minutes. The penalty was carried out at a distance of 7 meters. Skills can be assessed in a number of ways including observations, observations made to determine the child's development and attitudes in daily life continuously. Assessments that can be used to see the development of children's behavior include: 1. Portfolios, 2. Performance, 3. Assignment (project), 4. The work (product). The instrument is a tool that meets academic requirements as a tool to measure a measuring object or collect data about a variable [2]. The instrument was divided into two namely test and non-test. Test instruments include aptitude tests, intelligence tests, achievement tests and skills tests, and for non-tests including interviews, questionnaires or questionnaires, observation and check lists (suitable lists) and rating scales Basic motion skills in maturity are measured using tests [3]. "The test as an instrument for data collection is a series of exercises used to measure skills, knowledge, integration, ability or motor skills [4].

\section{METHOD}

This research is categorized under Research and Development with a goal of producing an educational product. [5] states that "Research and Development ( $\mathrm{R}$ and D) is an industry-based development model in which the findings of research are used to design new products and procedures, which then are systematically field-tested, evaluated, and refined until they meet specified criteria of effectiveness, quality, or similar standards".According to [6], Research and Development is a research method that is aimed to produce a specific product and put its effectivity to the test. Research and Development is a process and/or steps required in developing a new product or perfecting a previously existing product, and can be accounted for [3]. Based on the few opinions and definitions described above, it can be concluded that Research and Development program is a method of research for designing novel products or develop existing products, and systematically aims to search, find, formulate, revise (evaluate), develop, and test the effectivity of a finished product so that said product comes out superior, effective, and meaningful. The main step in development research [5]: 


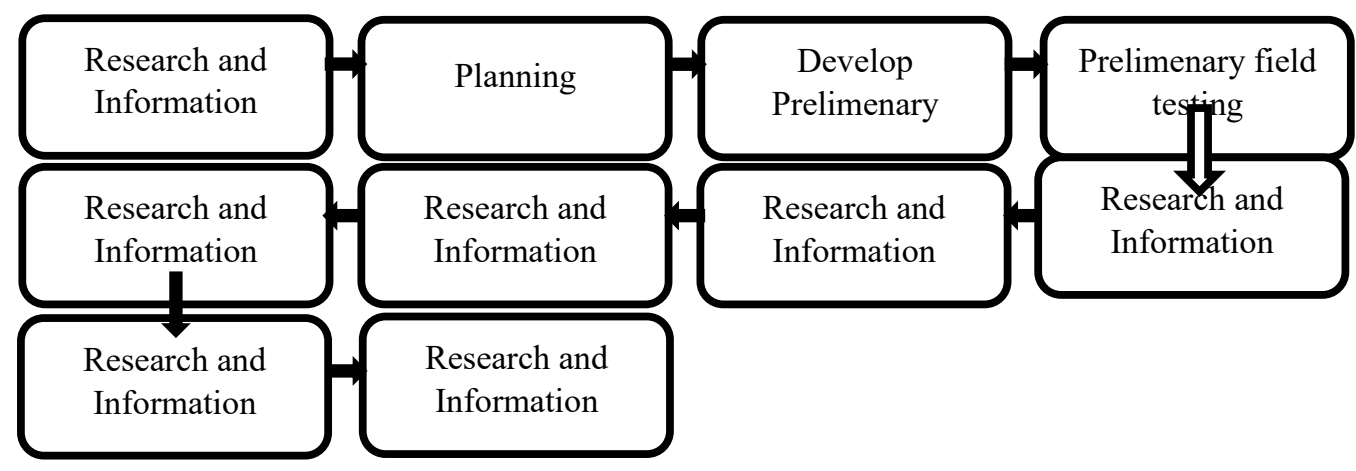

Figure 1. The main step in development research

Data processing in this research and development model utilized qualitative and quantitative analyses. Qualitative data during preliminary study were results from (1) interviewing primary school PE teachers, and (2) list of drawbacks and commentary from experts concerning the game model, which can be used to identify existing problems. On the other hand, descriptive quantitative analysis analyses the following data: (1) the scoring scale filled out by experts concerning the preliminary form of product prior to field testing, (2) observation results notes from experts concerning the model itself, (3) the experts' observatory data on model effectiveness, and (4) student questionnaire data.
For the data on the results of observation on the model for introduction of basic sepaktakraw techniques and a scoring on effectivity based on the Likert scale, there would be 3 kinds of score given, which are (1) Good/Effective. (2) Moderately Effective, and (3) Not Very Effective. The scoring results on observation items were then added up, and the total scores were converted to determine which categories they belong to. Conversion of points is done by adhering to standards of Benchmark Reference Assessment (PenilaianAcuanPatokan, PAP). When interpreting crude scoring result into values through a Benchmark Reference Assessment approach [7], a set of criteria and boundaries must be set, as would be elaborated on Table 1 .

Table 1. Score conversion guide

\begin{tabular}{|cc|}
\hline Formula & Category \\
\hline $\mathrm{X}<(\mu-1,0 \sigma)$ & Less/Not Very Effective \\
$(\mu-1,0 \sigma) \leq X<(\mu+1,0 \sigma)$ & Adequate/Quite Effective \\
$(\mu+1,0 \sigma) \leq X$ & Good/Effective \\
\hline
\end{tabular}

\section{RESULTS AND DISCUSSION}

The results of the research are how to do basic technical skills in handball in the form of tests of passing skills, shooting skills and dribbling skills. The renewal of the results of this study can be used as a Sports Test and Measurement in assessing the ability of the basic techniques of handball, because in the book Tests and measurements do not yet exist. In this stage the results of the test skills are presented in the form of an evaluation with an assessment, specifically to measure the process of implementing the motion.

Table 2 Scale of passing technique skills

\begin{tabular}{|c|c|c|}
\hline $\begin{array}{l}\text { The name of the test participant : } \\
\text { Gender }\end{array}$ & $\begin{array}{l}\text { Age } \\
\text { Test Date }\end{array}$ & \\
\hline SKILL FORM & MOTION INDICATORS & SCORE \\
\hline Early motion throws & $\begin{array}{l}\text { - } \quad \text { Passing uses the side upper } \\
\text { - } \quad \text { The body faces forward } \\
\text { - } \quad \text { Begins with } 3 \text { steps }\end{array}$ & $\begin{array}{l}123456 \\
123456 \\
123456\end{array}$ \\
\hline When Throwing & $\begin{array}{l}\text { - When throwing hands at an angle of } 90 \text { degrees } \\
\text { - The body is rotated towards the target pitch } \\
\text { - The ball must slide straight towards the pair } \\
\text { - The ball is loose beside the body }\end{array}$ & $\begin{array}{lllll}1 & 2 & 3 & 4 & 56 \\
1 & 23 & 3 & 56 \\
1 & 2 & 3456 \\
1 & 234556\end{array}$ \\
\hline Continuous throw & $\begin{array}{ll}\text { - } & \text { Throw your arms down } \\
\text { - } & \text { There is weight on both legs } \\
\text { - } & \text { Position ready to catch the ball }\end{array}$ & 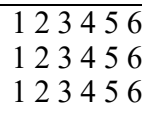 \\
\hline Initial motion catch & $\begin{array}{l}\text { - The body is ready } \\
\text { - The position of the hands in front of body } \\
\text { - } \quad \text { Both hands stick together and opened wide }\end{array}$ & $\begin{array}{llllll}1 & 2 & 3 & 4 & 5 & 6 \\
1 & 2 & 3 & 4 & 5 & 6 \\
1 & 2 & 3 & 4 & 5 & 6\end{array}$ \\
\hline
\end{tabular}


Implementation procedure:

a. Testy consists of 2 people facing each other. b. The distance between the testy is 15 meters and the distance of the field is 20 meters.

Table 3 Pre-test and post-test passing skills

\begin{tabular}{|ccccc|}
\hline Movement Assessment & Pre-test & Post-test & Gain & Category \\
\hline Understanding of SOP & 45.58 & 69.19 & 0.46 & Moderate \\
The success of the movement & 50.46 & 68.69 & 0.49 & Moderate \\
\hline
\end{tabular}

Table 4 Scale of shooting technique skills

\begin{tabular}{|c|c|c|}
\hline $\begin{array}{l}\text { The name of the test participant } \\
\text { Gender }\end{array}$ & $\begin{array}{l}\text { Age } \\
\text { Test Date }\end{array}$ & : \\
\hline SKILL FORM & MOTION INDICATORS & SCORE \\
\hline Start shooting movement & $\begin{array}{l}\text { - Shooting technique with standing or } \\
\text { flying shoot } \\
\text { - Throw } 2 \text { times to the feeder } \\
\text { - Leg position when standing }\end{array}$ & $\begin{array}{l}123456 \\
123456 \\
123456\end{array}$ \\
\hline When shooting & $\begin{array}{l}\text { - Footsteps with } 3 \text { steps } \\
\text { - Body shifts towards right, left and } \\
\text { front } \\
\text { - The feet do not step on the line or } \\
\text { exceed the line } \\
\text { - Body position flying in the air and } \\
\text { pointing inward } \\
\text { - The ball is released when floating } \\
\text { - Leads to goals for which there is value }\end{array}$ & $\begin{array}{l}123456 \\
123456 \\
123456 \\
123456 \\
123456 \\
123456\end{array}$ \\
\hline Shooting motion & $\begin{array}{ll}\text { - } & \text { Throw your arms down } \\
\text { - } & \text { There is weight on both legs } \\
\text { - } & \text { Position ready to catch the ball } \\
\end{array}$ & $\begin{array}{lllll}123456 \\
123456 \\
123456\end{array}$ \\
\hline Initial motion catch & $\begin{array}{l}\text { - Harmony of the whole series of } \\
\text { shooting motion }\end{array}$ & 123456 \\
\hline
\end{tabular}

Implementation procedure:

a. Early testy is given 3 shooting opportunities in

the right, left and centre wing positions.

b. The ball is passed by the pitcher.

Table 5 Pre-test and post-test shooting technique skills

\begin{tabular}{|ccccc|}
\hline Movement Assessment & Pre-test & Post-test & Gain & Category \\
\hline Understanding of SOP & 45.58 & 69.19 & 0.46 & Moderate \\
The success of the movement & 50.46 & 68.69 & 0.49 & Moderate \\
\hline
\end{tabular}

Table 6 Dribbling technique skills scale

\begin{tabular}{|c|c|c|}
\hline $\begin{array}{l}\text { The name of the test parti } \\
\text { Gender }\end{array}$ & $\begin{array}{l}\text { Age } \\
\text { Test Date }\end{array}$ & \\
\hline SKILL FORM & MOTION INDICATORS & SCORE \\
\hline start dribbling movement & $\begin{array}{l}\text { - The ball is held with one hand } \\
\text { - Stand with both feet parallel or one foot in front } r \\
\text { - Knee slightly bend }\end{array}$ & 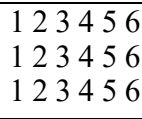 \\
\hline When dribbling & $\begin{array}{l}\text { - Foot stepping alternately } \\
\text { - The ball is reflected to the floor with a zig-zag track } \\
\text { - The ball can be caught with the same and different hands } \\
\text { - The ball must not be held or present when stopped }\end{array}$ & 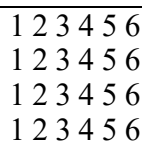 \\
\hline Shooting motion & $\begin{array}{l}\text { - Throw your arms down } \\
\text { - There is weight on both legs } \\
\text { - } \quad \text { Position ready to catch the ball }\end{array}$ & 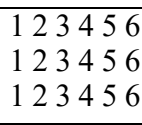 \\
\hline Initial motion dribbling & - Harmony of the whole series of shooting motion & 123456 \\
\hline
\end{tabular}


Implementation procedure

a. Each test is given 1 chance

Table 7 Pre-test and post-test dribbling skills

\begin{tabular}{|ccccc|}
\hline Movement Assessment & Pre-test & Post-test & Gain & Category \\
\hline Understanding of SOP & 45.58 & 69.19 & 0.46 & Moderate \\
The success of the movement & 50.46 & 68.69 & 0.49 & Moderate \\
\hline
\end{tabular}

1) A value of 1 is given if it does not even display the correct motion.

2) A value of 2 is given when displaying a movement that is incompatible with the indicator.

3) A value of 3 is given if the movement matches the indicator and the movement is incorrect.

4) A value of 4 is given if the movement matches the indicator and the movement is not perfect.

5) A value of 5 is given if the movement matches the indicator and the movement is almost perfect.

6) A value of 6 is given if the movement matches the indicator and the motion is perfect.

\section{CONCLUSION}

The conclusion of this study is that the test instrument is still at the stage of understanding the procedures for implementation and the success of the movement with value indicators. In the future, it will be developed to look for norms about assessment so that they can be categorized for men and women.

\section{REFERENCES}

[1] M. Joko, Pranawa, Adi., Metode dan dasar-dasar Handball. Semarang: CV. Presisi Cipta Media, 2016.

[2] E. Susanto, "Pengembangan tes keterampilan dasar olahraga bola tangan bagi mahasiswa," J. Penelit. dan Eval. Pendidik., 2017.

[3] N. S. Sukmadinata, Kurikulum dan Pembelajaran Kompetensi. Bandung: PT Refika Aditama, 2012.

[4] P. D. Sugiyono, metode penelitian kuantitatif, kualitatif,dan R\&D. 2016.

[5] M. D. Gall, J. P. Gall, and W. R. Borg, "Educational Research: An Introduction, 8th Edition," Educ. An Introd., 2006.

[6] Sugiyono, "Metode Penelitian Kuantitatif, Kualitatif dan R \& D.Bandung:Alfabeta.," Metod. Penelit. Kuantitatif, Kualitatif dan R D.BandungAlfabeta., 2012.

[7] S. Azwar, Penyusunan Skala Psikologi. Yogyakarta: Pustaka Pelajar, 2012. 